\title{
It Is All About "Hope": Evidence on the Immigrant Optimism Paradox
}

Héctor Cebolla-Boado ${ }^{1}$, Department of Sociology 2, UNED, Madrid, Spain

Amparo González Ferrer, CSIC, Madrid, Spain

Yasemin Nuhoḡlu Soysal, Department of Sociology, University of Essex, Colchester, UK

\begin{abstract}
This paper investigates the immigrant educational optimism hypothesis using data from Spain. Specifically, we examine the nature of higher educational expectations among migrant-origin families in comparison to non-migrant families, conditional upon students' prior school performance and social background. Our dataset includes more than two thousand students in secondary schools in Madrid and, as an innovation in the literature, allows identical analyses for dyads of parents and children. Our results suggest that immigrant optimism is more likely the result of positive selection of parents as first movers than lack of understanding among migrant families of how to process information regarding their children's educational prospects in the host country. Interestingly, students from migrant-origin families themselves do not share the same optimism as their parents. We argue that migration is linked with "hopeful" aspirations and identities, which is in line with research showing selection among labour migrants on the basis of unobservable characteristics.
\end{abstract}

Keywords: Hope, Migrant optimism, Dyadic analysis, Educational expectations, Migrant selectivity, Spain

Despite falling behind in school and lacking resources, immigrant children are broadly described as motivated learners and aspiring students, with positive attitudes towards education. Already by the 1970s, sociologists saw educational expectations as a mediator between social origin and educational outcomes and had documented that, when compared with Caucasians, educational expectations among Black Americans were less consequential for achievement. This regularity was labelled the "expectation-achievement paradox" and further extended to the children of immigrant families, where it was relabelled as the "immigrant optimism paradox" (Kao and Tienda 1995). The topic has since remained a vibrant field of inquiry for scholars interested in migration, ethnic minorities and education. Some scholars see optimism as a form of capital that facilitates social mobility (Van De Werfhorst and Van Tubergen 2007). In specific institutional settings, such as choice driven education systems, immigrant optimism has been shown to improve educational outcomes (Nygard 2017; Dollmann 2015; Jackson, Jonsson, and Rudolphi 2012). Others regard immigrant optimism as irrelevant since immigrant families do not manage to convert expectations into behaviour (Cummings et al. 2012; Engzell 2018).

Despite immense analytical interest, the literature on immigrant optimism has spent more time documenting optimism in different national settings than searching for the factors that underlie it. It is precisely here where our paper seeks to contribute, by opening up the black-box of the "optimism paradox". To do so we produced a unique dataset from

\footnotetext{
${ }^{1}$ Hector Cebolla-Boado: hector.cebolla@gmail.com
} 
Spain that allows us to analyse dyads of parents and children in Madrid. Spain has been on the receiving end of intense migration inflows over the last two decades. Its transformation from an emigration to an immigration society took place in only a few years. All of which makes Spain an interesting case study, as a large portion of the student population has been influenced by the short-term dynamics of migration that shape educational success (Cebolla Boado and González Ferrer 2013).

\section{The sociological study of optimism among migrant and non-migrant origin students}

Outside the US, immigrant optimism has been documented in a large number of European countries including Belgium (Teney, Devleeshouwer, and Hanquinet 2013), Germany (Salikutluk 2016), the Netherlands (Van De Werfhorst and Van Tubergen 2007), Spain (Cebolla Boado and Martínez de Lizarrondo 2015; Gil-Hernández and Gracia 2018), Sweden (Jonsson and Rudolphi 2011), and the UK (Fernández-Reino 2016). Only the evidence from Italy is less in line with the general European trend (Minello and Barban 2012). At the risk of simplifying a complex scholarly tradition, we identify three main suggested explanatory mechanisms: anticipatory discrimination, information deficit and migrant selectivity.

The most common explanations of immigrant optimism emphasize anticipatory discrimination and information deficit (Tjaden and Hunkler 2017). Particularly in light of Asian Americans' extraordinary educational success, willingness to overcome racial discrimination (Xie and Goyette 1997; Sue and Okazaki 1990) and, on a cultural level, effective use of shadow education (Byun and Park 2012), have been linked with higher aspirations. There is no consensus regarding the impact of anticipation of discrimination as being responsible for educational optimism (Fernández Reino 2016), and we do not examine this possibility in our paper. Kao and Tienda (1998) have already argued that insufficient information about college financial aid packages and social segregation in the US foment unrealistic educational expectations among immigrant origin youth. One can conceive of immigrant families as social units with insufficient information about the functioning of their host society and its education system. Information about social rules and institutional logics can be country specific. Understanding the implications of school results over time requires familiarity with many school rules of both an implicit and explicit nature, as well as accumulation of knowledge about the experience of others in meaningful reference groups. Previous research has shown that individual assessment of one's academic competences may vary by ethnicity (Okeke et al. 2009). Accordingly,

H1: The higher educational expectations of migrant-origin children and their families, conditional upon their prior school performance, are due to a lack of information about the education system and its functioning in their society of residence.

Furthermore, information deficit should be stronger among migrant parents than among their children, as they are the ones in direct contact with the host country education system.

Early accounts of optimism also suggest positive selection of first generation immigrants, whose impulse for social mobility may boost their stated expectations (Kao and Tienda 1995). According to this idea, migrants are not a representative sample of nonmigrants but a differentiated group on both observed and unobserved characteristics. Research into selection on observable characteristics has focused on at migrants coming from generally more advantaged backgrounds than the average population in the origin country (Feliciano and Lanuza 2017; Ichou 2014; van de Werfhorst and Heath 2019). 
Researchers interested in selection on unobserved characteristics have included focusing on specific personality traits such as ambition and risk taking (Polavieja, Fernández-Reino, and Ramos 2018). Another important intervention, beyond the immigration literature, suggests studying educational expectations as "moral claims" and as identity (Frye 2012: 1566-67). Set against the rational choice bias in the mainstream stratification literature, this line of argumentation interprets "pervasive optimism" as an assertion of personal identity and a projection of self-transformation in line with an idealized future. Such identity projections are increasingly shaped by educational ideologies that are transnationally transmitted, which provide aspirational narratives of self that recent scholarship on selectivity has identified as unobservable characteristics (Cebolla-Boado and Soysal 2017; Soysal and Cebolla-Boado 2020). If immigrants are a positively selected group in terms of unobserved characteristics, ranging from being more aspirational to being more likely to enter into paths that favor upward social mobility, migrant-origin families may represent a stimulating environment for the formation of expectations. Accordingly,

H2: Migrants are more hopeful when compared with non-migrants due to positive selection, and this makes them less dependent on school results when formulating educational expectations. The effect of positive selection should be far more evident among first movers (parents) than among tied migrants (migrant children) and the so-called second generation.

The empirical test of these hypotheses is not always easy since we often lack appropriate proxies for key independent indicators (i.e. proxies of information and perceptions of attainment) and it is difficult to meet the demanding analytical conditions they require (e.g. dyads of parents and children). While our dataset allows us to overcome these two difficulties, the test of our hypotheses is far from a definite contrast of causal arguments, but rather an indirect confirmation of their empirical importance as explanations of immigrant optimism.

\section{Data: Chances 2011 Survey}

In this paper we utilize a unique survey, Chances 2011, which sampled adolescents enrolled in years ten and eleven of compulsory education (ages fourteen to sixteen) in the city of Madrid in the first half of 2011. The school sample was constructed in two stages. In the first stage, twenty-four neighbourhoods were selected from four different strata constructed by combinations of two indicators:

1. The total number of foreign-born children aged fourteen to sixteen from the ten largest migrant groups in this age band living in Madrid in 2009. This indicator guaranteed our sample would contain a sufficient number of foreign-born students to allow separate analyses by migrant origin.

2. A combination of the percentage of the foreign-born population living in the neighbourhoods of Madrid in 2009 and the socioeconomic profile of the neighbourhood, according to the official classification provided by the City Statistics Office. The neighbourhoods were classified into four different categories depending on the percentage of foreigners living there, i.e.: first quartile: 4 to 9 per cent; second quartile: 10 to 17 per cent; third quartile: 18 to 24 per cent; and fourth quartile: 25 to 42 per cent. Neighbourhoods from each quartile were selected across different socioeconomic profiles, excluding the ones classified as elite and of high 
socioeconomic level, since the number of adolescents of migrant origin in such neighborhoods is very low. The neighbourhoods excluded from the sample design were those with less than nine per cent of foreign-born population (thirteen neighborhoods out of 133 in the city) They had only 3 per cent of the total foreignborn population in Madrid at the time of the sample design, and largely coincided with upper class neighbourhoods. Our final sample includes residential districts where the foreign-born population ranges from 9 to 42 per cent of their total population, with an average of 23 per cent.

In a second stage, we randomly selected thirty schools (state and private) out of a total of 120 secondary schools in the twenty-four neighbourhoods chosen in the first stage. We surveyed all students - of both migrant and non-migrant origins- in all classrooms of years ten and eleven in the selected schools, which resulted in a total sample of 2,712 adolescents. The percentage of foreign-born students in those thirty schools ranged from 4 to 80 per cent, with an average of thirty-five per cent. Thus, in terms of migrant concentration, the final sample reflects the diversity of the city and of the municipal education system.

Because of our sampling strategy, the Chances 2011 sample is biased towards schools with more migrants. In order to reduce ethnic heterogeneity within the migrant category, we restrict our analyses to the children of Latin Americans only, by far the largest migrant group in Spain. Our questionnaires were designed in parallel for students and their parents. All students completed the questionnaire in the classroom during fiftyfive minutes of class time under the supervision of their teacher and a researcher from the Chances 2011 project team. Parents of the surveyed students completed the questionnaire (translated into home language when needed) at home. The response rate among parents was forty-five per cent and mothers represented seventy-four per cent of respondents.

From the 1,079 children in our sample with both parents born abroad, 791 were of Latin American origin. Our analytical sample is further reduced because of the treatment given to the missing values (Table 1).

Table 1. Chances 2011 sample size

\begin{tabular}{lccc}
\hline & $\begin{array}{l}\text { Full sample } \\
\text { (all migrants) }\end{array}$ & $\begin{array}{l}\text { Full sample } \\
\text { (Latin } \\
\text { Americans) }\end{array}$ & $\begin{array}{l}\text { Analytic } \\
\text { sample }\end{array}$ \\
\hline Non-migrant parents & 794 & 794 & 742 \\
Migrant parents & 317 & 309 & 306 \\
Non-migrant children & 1,561 & 1,561 & 1,394 \\
Migrant children & 1,079 & 791 & 784 \\
\hline
\end{tabular}

\section{Analysis}

\section{$\underline{\text { Variables }}$}

All students and parents in Chances 2011 were separately asked about their/their children's expected educational trajectories: "Which is the highest educational level you expect [your child] to reach?" Answers to this question ranged from 1 to 5: (1)"Until the end of compulsory schooling" (2)"Basic vocational training" (3)"Until the completion of upper secondary education" (4)"Advanced vocational training" (5)“University degree". For the 
sake of simplicity, in the coming analyses, we have re-codified our dependent variable into a dummy, using " 1 " if university is the selected option and " 0 " otherwise. Students were asked an additional question regarding their expectations: "On a scale of zero to ten how likely do you think it is that you will study tertiary education?" This is the variable we use in our descriptive analysis below.

While expectations are abstract desires, the optimism argument requires looking into expectations conditional upon assessment of school performance - that is to what extent migrant parents and their offspring regard their educational expectations as achievable, given the school results the children achieved. It is essential for our hypotheses to differentiate between the impact of having different levels of information and that of processing the information conveyed by school results in a differential manner. We are specifically interested into what extent students and their parents are able to realistically infer probabilities of reaching university level education on the basis of their academic performance. The question that proxies this interest in the survey is: "Do you think that youlyour child's performance is enough to study tertiary education?" Response categories are three: "Yes, enough to study tertiary education", "No, not enough" or "I do not know". The wording allows us to use the answers as indicators of whether students and their parents deduce from observed school results likelihood of entering the university cycle.

\section{Descriptive evidence}

We start our analysis by looking at how differently migrant-origin and non-migrant origin children see their own chances of attaining tertiary education on a scale of zero to ten (Figure 1). Migrant-background students are less represented among those with expectations of a higher likelihood of studying at university. Similarly, there are also fewer of them among those who happen to be highly pessimistic about their chances. Migrantorigin students are more likely to be situated in the middle of the distribution, whereas nonmigrant students are more likely to choose the extreme response categories. 
Figure 1. Children's and parents' assessment of school performance by grade retention and migrant background

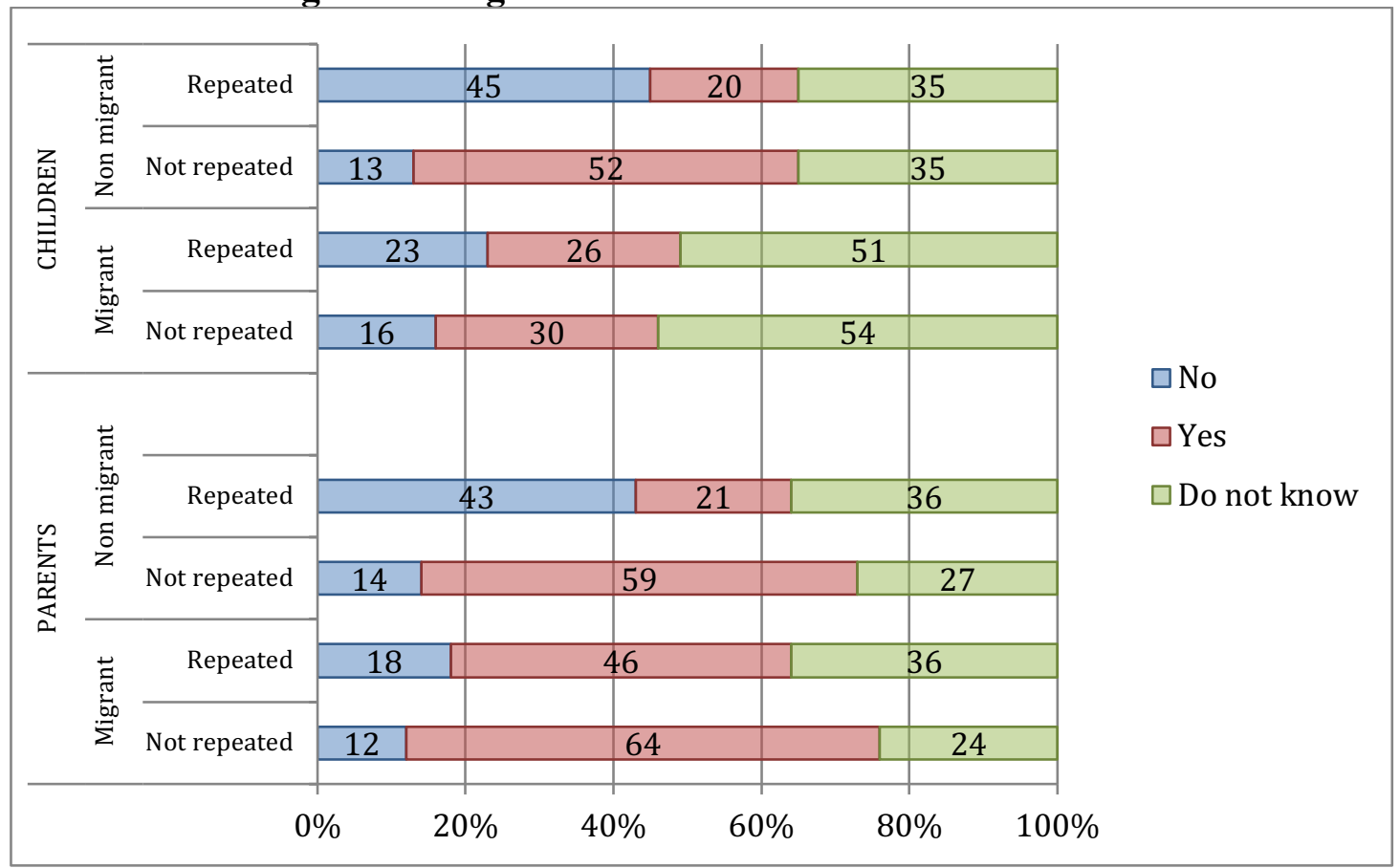

Source: Chances 2011 ("Do you think your/ your child's performance is enough to attain tertiary education?")

These differences in self-estimated chances of attending university may well reflect differences in children's school performance. We know that the school performance of migrant-background students systematically lags behind that of non-migrants. However, because of information constraints, migrants may feel more uncertain about the significance of school performance for transition rates (grades send signals about the likelihood of succeeding in subsequent stages). We explore this possibility using the variable that registers assessments of whether the child's school performance is enough to attain tertiary education, with responses "no" "yes" and "I don't know". Figure 2 looks at the answers given by parents and children by migrant status and children's school performance. For school performance, we use a common proxy in the Spanish research literature, that of repeating the school year, which in Spain affects over one third of students. From the plot, we can clearly see that the expectations of migrant and nonmigrant families are not equally sensitive to poor student performance. The downward adjustment of expectations in light of poor scholastic performance is more important for non-migrant than migrant families. While among those students that have repeated, migrants answering "no" (whether school performance is enough to attain tertiary education) are only 23 per cent, among non-migrants they are 45 per cent. The difference is slightly larger between migrant and non-migrant parents. 
Figure 2. Migrant and non-migrant parental differentials in conditional expectations by assessed level of school performance

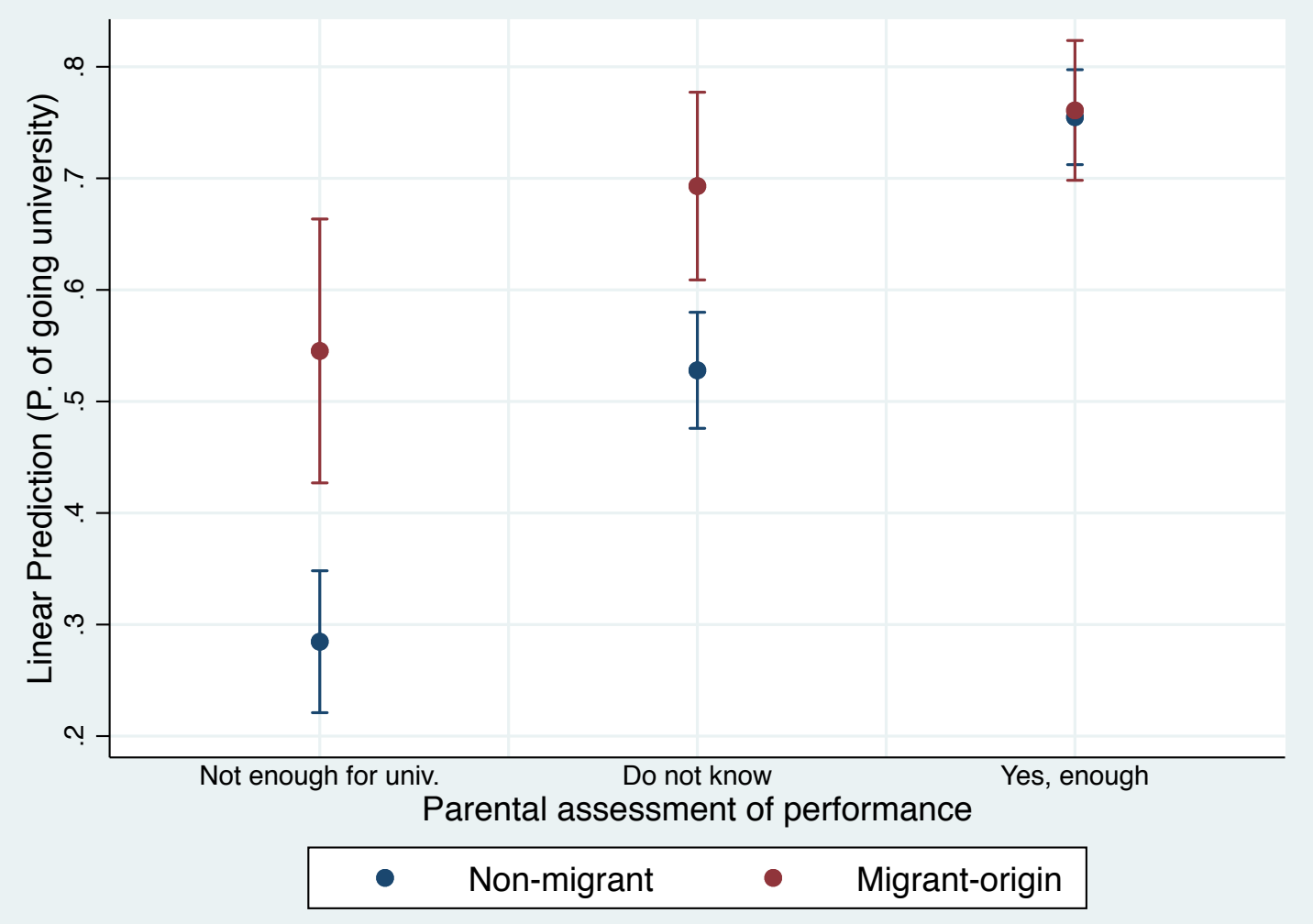

Legend: estimated from Model 3 in Table 2.

\section{$\underline{\text { Multivariate analysis }}$}

While there are evident signs of optimism at this descriptive level, the crucial step is to confirm the expected pattern of optimism using multivariate analyses. Our hypotheses suggest looking at the relationship between information about the education system and formation of educational expectations. We model migrant and non-migrant differentials in conditional expectations by assessed level of school performance.

We conduct two sets of analyses in which the responses given by children and parents can be compared. The models are run first for the parents and secondly for the children. In each case we run three nested models. The first measures the net differences in migrant status ( 0 non-migrant; 1 migrant) regarding educational expectations (studying at university level, our dependent variable). This model controls for an objective measure of performance (whether the student has repeated any school year), a measure of social background (the highest level of parental education: primary, secondary or tertiary), and the student's gender ( 0 male; 1 female). The second model controls for our proxy of information, namely the assessment of the student's school performance (whether performance is good enough to study at university) by the parents and students themselves. The third model introduces a two-way interaction between our proxy of information and migrant status, as a way of indirectly testing our selection hypothesis (Table A.1 in the Appendix provides the descriptives for all the variables used).

\section{Method}


Because of the clustering of students across schools our data is hierarchically organized, but variation between schools is not the main target of our analyses, we therefore use linear fixed effect probability models in which school characteristics are fully controlled allowing for a proper investigation of effects within school level. The basic specification of this modelling is:

$\mathrm{y}_{\mathrm{ij}}-\mathrm{y}_{\mathrm{j}}=\left(\mathrm{x}_{\mathrm{ij}}-\mathrm{x}_{\mathrm{j}}\right) \beta+\varepsilon_{\mathrm{ij}}-\varepsilon_{\mathrm{j}}$

where $y_{i j}$ is the average value in the dependent variable for individual $i$ in school $j$, and $y_{j}$ is the average value for $\mathrm{i}$ in school $\mathrm{j}$.

\section{Findings}

The models conducted with the responses given by parents provide insightful information. The first model in Table 2 shows that our objective measure of performance actually correlates in the predicted way with parental educational expectations for their offspring (when the student has repeated a school year, expectations are downgraded). Importantly to our argument, migrant parents are conditionally more likely to expect their children to reach tertiary education than the parents of non-migrant background individuals. In fact, the expectation among migrant parents that their children will attain university education is 15 percentage points above that of non-migrant parents. This is, thus, a direct confirmation of "immigrant optimism" among parents in our data. In other words, growing up in a migrant household may represent a more stimulating environment where the parental expectations, regardless of social origin, are higher than the expectations of parents in non-migrant households. Note that this model also reveals that the clustering of students across schools is of little importance in understanding conditional expectations (the inter class correlation coefficient only amounts to 6 per cent of the total variation in our dependent variable).

The second model (Table 2) shows that parental optimism among migrant families remains even when controlling for the assessment that parents make of the level of school performance of their children. While the slope associated with being a migrant parent decreases by one-third (from 0.15 to around 0.1 ), there is still some unexplained heterogeneity making migrant parents a more expectant population. Parents who think that the current level of academic performance of their offspring is enough for them to study at university are indeed more likely to expect that they will finally study in tertiary education when compared with those who think the opposite. Parents who are uncertain about whether the level of academic performance of their child is high enough to achieve the wish of attending university have higher expectations than the reference group (those assessing the current school results of their children as being not good enough). We interpret the results of this model as a contradiction to the argument stated in the first hypothesis that a certain information deficit explains the unaccounted variation in expectations that make migrant parents more optimistic.

Our second hypothesis tested in model 3 (Table 2) states that migrants may process information differently from non-migrants. The existence of a significant interaction between the parental assessment of the school performance and the migrant status indeed suggests that migrant and non-migrant parents react differently to school performance. 
Table 2. Linear probability model (fixed effects), Parents

\begin{tabular}{|c|c|c|c|c|c|c|c|}
\hline & & (1) & & (2) & & (3) & \\
\hline $\begin{array}{l}\text { Migrant-origin } \\
\text { Grade repetition } \\
\text { Parental education } \\
\text { (ref. primary or less) } \\
\text { Female student }\end{array}$ & $\begin{array}{l}\text { Secondary } \\
\text { Tertiary }\end{array}$ & $\begin{array}{l}0.150 * * * \\
-0.444 * * * \\
0.047 \\
0.212 * * * \\
0.072 * *\end{array}$ & $\begin{array}{l}(0.03) \\
(0.03) \\
(0.04) \\
(0.05) \\
(0.03)\end{array}$ & $\begin{array}{l}0.099 * * \\
-0.354 * * * \\
0.053 \\
0.190 * * * \\
0.048^{*}\end{array}$ & $\begin{array}{l}(0.03) \\
(0.03) \\
(0.04) \\
(0.04) \\
(0.03)\end{array}$ & $\begin{array}{l}0.261 * * * \\
-0.351 * * * \\
0.051 \\
0.180 * * * \\
0.044 *\end{array}$ & $\begin{array}{l}(0.07) \\
(0.03) \\
(0.04) \\
(0.04) \\
(0.03)\end{array}$ \\
\hline $\begin{array}{l}\text { Assessed } \\
\text { performance } \\
\text { (ref. not enough) }\end{array}$ & $\begin{array}{l}\text { Do not know } \\
\text { Yes, enough }\end{array}$ & & & $\begin{array}{l}0.226 * * * \\
0.402 * * *\end{array}$ & $\begin{array}{l}(0.04) \\
(0.03)\end{array}$ & $\begin{array}{l}0.243 * * * \\
0.470 * * *\end{array}$ & $\begin{array}{l}(0.04) \\
(0.04)\end{array}$ \\
\hline Interactions & $\begin{array}{l}\text { Migrant*Do } \\
\text { not know } \\
\text { Migrant*Yes, } \\
\text { enough }\end{array}$ & & & & & $\begin{array}{l}-0.095 \\
-0.253 * *\end{array}$ & $\begin{array}{l}(0.08) \\
(0.08)\end{array}$ \\
\hline Constant & & $0.586 * * *$ & $(0.0446)$ & $0.316^{* * *}$ & $(0.05)$ & $0.284 * * *$ & $(0.05)$ \\
\hline Model information & $\begin{array}{l}\text { Rho } \\
\text { Sigma(e) } \\
\text { Sigma(u) } \\
\text { N }\end{array}$ & $\begin{array}{l}0.0642 \\
0.109 \\
0.416 \\
1048\end{array}$ & & $\begin{array}{l}0.0681 \\
0.106 \\
0.391 \\
1048\end{array}$ & & $\begin{array}{l}0.068 \\
0.105 \\
0.388 \\
1048\end{array}$ & \\
\hline
\end{tabular}

Standard errors in parentheses

$* \mathrm{p}<0.10, * * \mathrm{p}<0.05, * * * \mathrm{p}<0.001$

The joint interpretation of interactive and additive effects is summarized in a plot shown in Figure 3. As can clearly be seen the pattern of migrant and non-migrant differentials in conditional expectations changes with the assessed level of school performance. Migrants are more "optimistic" when they estimate that their offspring's current performance is not good enough for them to study tertiary education. The difference between these two groups is also significant when parents are uncertain about the level of level of school success of their children. By contrast, there are no differences by the migrant status of parents when they estimate that their child's performance is good enough. In other words, migrant parents are more optimistic when their children's performance put them at risk of failing to reach tertiary education. The probability of parents expecting to see their poorly performing children at university is almost twice as high as when they are migrants as when they are non-migrants. 
Figure 3. Migrant and non-migrant children differentials in conditional expectations by assessed level of school performance

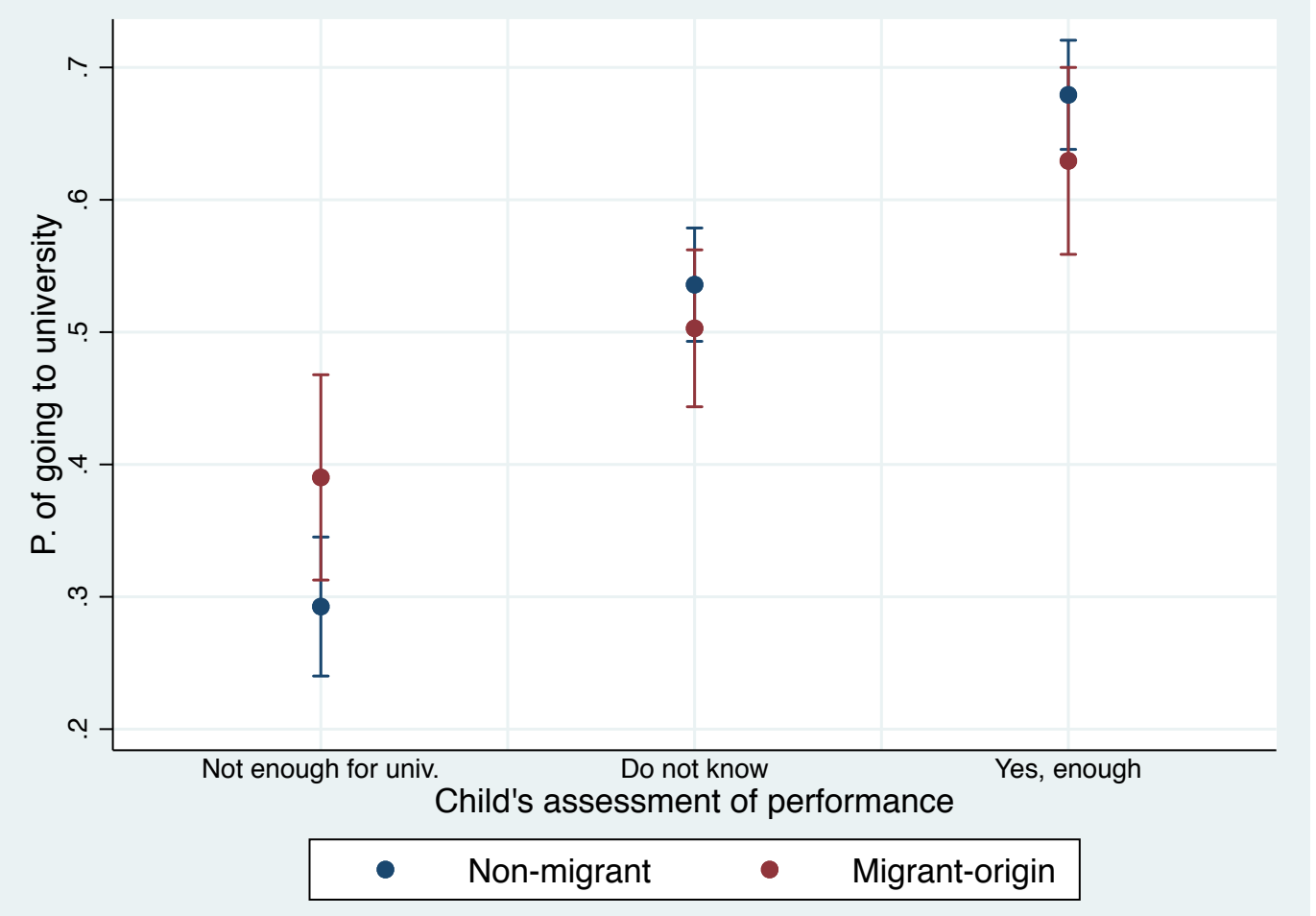

Legend: estimated from Model 3 in Table 3.

The set of models estimated using the children's responses provide somewhat different results (Table 3; main results summarized in Figure 4. Interestingly, in our data, children of migrant parents are not more optimistic than the children of non-migrant parents. There are no significant differences in the likelihood of students expecting to reach tertiary education conditional on parental educational background (model 1) and objective performance (model 2). In other words, optimism is a family construct that may originate among parents and not children. Actually, this result is robust when we consider the assessment children make of their own school performance. Only when the model includes the interaction between assessment of school results and migrant status does the additive effect of migrant background turn out to be positive (model 3). By contrast, the interactions are highly negative when students perceive that they are good enough or uncertain (with the reference being "no"). 
Table 3. Linear probability model (fixed effects). Children

\begin{tabular}{|c|c|c|c|c|c|c|c|}
\hline & & \multicolumn{2}{|l|}{ (1) } & \multicolumn{2}{|l|}{ (2) } & \multicolumn{2}{|l|}{ (3) } \\
\hline $\begin{array}{l}\text { Migrant-origin } \\
\text { Grade repetition } \\
\text { Parental education } \\
\text { (ref. primary or less) } \\
\text { Female student } \\
\text { Age/age of arrival }\end{array}$ & $\begin{array}{l}\text { Secondary } \\
\text { Tertiary }\end{array}$ & $\begin{array}{l}-0.030 \\
-0.387 * * * \\
0.036 \\
0.220 * * * \\
0.0436 * * \\
-0.003 \\
\end{array}$ & $\begin{array}{l}(0.0379) \\
(0.0208) \\
(0.03) \\
(0.04) \\
(0.02) \\
(0.00)\end{array}$ & $\begin{array}{l}-0.003 \\
-0.324 * * * \\
0.032 \\
0.187 * * * \\
0.029 \\
0.001\end{array}$ & $\begin{array}{l}(0.04) \\
(0.02) \\
(0.03) \\
(0.03) \\
(0.02) \\
(0.00)\end{array}$ & $\begin{array}{l}0.010^{*} \\
-0.317 * * * \\
0.0328 \\
0.187^{* * *} \\
0.0308 \\
0.000\end{array}$ & $\begin{array}{l}(0.05) \\
(0.02) \\
(0.03) \\
(0.03) \\
(0.02) \\
(0.00)\end{array}$ \\
\hline $\begin{array}{l}\text { Assessed performance } \\
\text { (ref. not enough) }\end{array}$ & $\begin{array}{l}\text { Do not know } \\
\text { Yes, enough }\end{array}$ & & & $\begin{array}{l}0.199 * * * \\
0.338 * * *\end{array}$ & $\begin{array}{l}(0.02) \\
(0.03)\end{array}$ & $\begin{array}{l}0.242 * * * \\
0.386 * * *\end{array}$ & $\begin{array}{l}(0.03) \\
(0.03)\end{array}$ \\
\hline Interactions & $\begin{array}{l}\text { Migrant*Don't know } \\
\text { Migrant*Yes, enough }\end{array}$ & & & & & $\begin{array}{l}-0.128 * * \\
-0.153 * *\end{array}$ & $\begin{array}{l}(0.05) \\
(0.06)\end{array}$ \\
\hline Constant & & $0.625 * * *$ & $(0.0656)$ & $0.351 * * *$ & $(0.07)$ & $0.321 * * *$ & $(0.07)$ \\
\hline Model information & $\begin{array}{l}\text { Rho } \\
\text { Sigma(e) } \\
\text { Sigma(u) } \\
\text { N }\end{array}$ & $\begin{array}{l}0.023 \\
0.438 \\
0.068 \\
2178\end{array}$ & & $\begin{array}{l}0.020 \\
0.422 \\
0.060 \\
2178\end{array}$ & & $\begin{array}{l}0.020 \\
0.422 \\
0.060 \\
2178\end{array}$ & \\
\hline
\end{tabular}

Standard errors in parentheses

$* \mathrm{p}<0.10, * * \mathrm{p}<0.05, * * * \mathrm{p}<0.001$

Figure 4, which plots the results corresponding to children's expectations, shows that migrant and non-migrant origin children are much more similar than their parents. There are no traces of significant differences between these two groups, although it is possible that with larger sample sizes we could have encountered more optimistic students from migrant backgrounds whose assessed performance is reported as not being good enough (note that in that specific category, the marker for those of migrant origin is clearly above that for those of non-migrant origin).

Figure A.1. Results of the dyadic approach to modelling parental and children's expectation using HLM models (clusters are households).

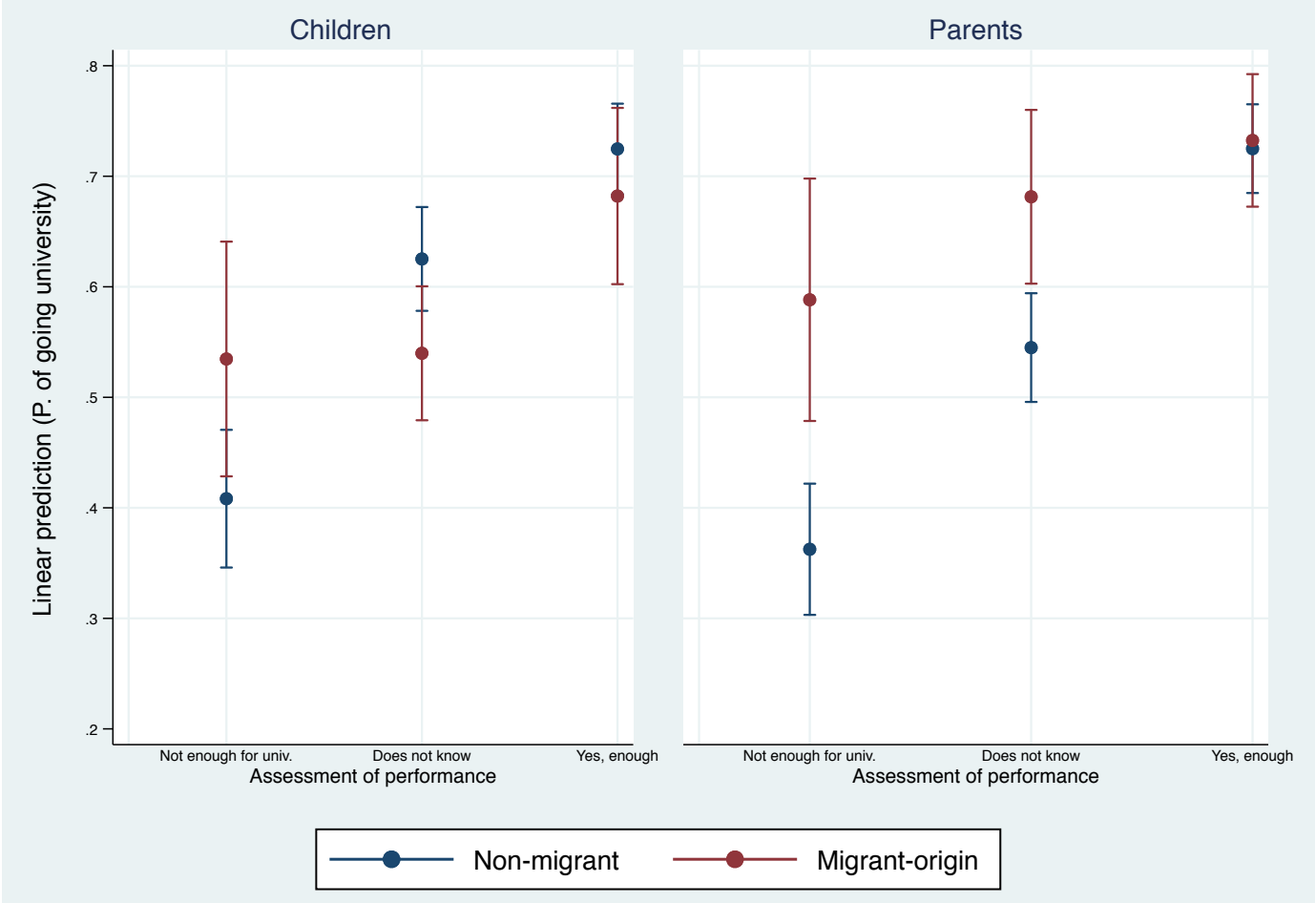

Source: Results obtained from model shown in Table A.2.

Complementary analyses and sensitivity checks 
Our results are stable if other model specifications are used for the estimation. Specifically, many of our arguments are potentially sensitive to time since arrival in Spain. Controlling for this variable additively or interacting it with migrant status or the assessment of performance, does not change our results.

Since the test of our hypotheses is only indirect and made by implication, we have conducted a number of complementary analyses in order to disprove the argument that information deficit creates optimism. Critics of our approach may suggest that as time of residence in destination passes, migrants catch up with non-migrants in terms of the information needed to form similar educational expectations, which will end any trace of migrant optimism. This could apply to both children and parents. Sensitivity checks not presented here, but available upon request, rule out this possibility, particularly for children. Figure 4 indicates that the educational expectations of migrant mothers may adjust to some extent, however in our data we find no grounds to suggest that this is a statistically significant regularity.

Similarly, for parents with more than one child, it could be argued that information deficit may not be important when reporting on their younger children since they may have learned from the prior experiences of their elder children. Thus, parental expectations regarding their later-born children should be more adjusted to reality if optimism is created by a lack of accurate information. Expectations of migrant parents are no different when they refer to a first or later-born child. Detailed results are available upon request.

Another way of ruling out the possibility of information deficits creating optimism among parents is to see whether parents whose assessment differs from that of children are indeed those optimistic. The argument here is that more uncertain parents (about their children's potential could be more inclined to show high expectations so as not to disincentivize their offspring. This possibility is discarded in our results, which are available upon request.

As a further sensitivity check, if selection creates optimism, we would expect that migrant parents, more than non-migrant parents, should report that they would be frustrated if, finally, their children did not make it to university. This is precisely what we find in our analysis. Results are available upon request.

While our modelling strategy is based on linear probability models, we have also estimated logistic regressions to calculate average marginal effects from the resulting estimates. This did not bring about any substantive changes in our conclusions. Our results are not sensitive to estimating multilevel models with random constants instead of school fixed effects.

Finally, we have re-estimated all our results clustering observations by households (dyads of parents and child) instead of by schools (students within schools). This might be the most appropriate modelling way to reflect the dyadic potential of our data since rho amounts to 43 percent as opposed to a neglectable two percent if using schools as the key cluster. Yet, when following this approach, we of course loose a large part of our sample of students given that the parental sample is significantly smaller. The Appendix shows the results of this joint analysis for parents and children in Table A. 2 and eases the comparison of results with the ones discussed in the main text of our paper through Figure A.1 
(Appendix). Reassuringly, the results of our analyses replicate those of the models discussed in our empirical section.

\section{Conclusion}

To the best of our knowledge, ours is among the very few studies that simultaneously analyses parents and children's educational expectations by migrant status. Using the logic of dyads of parents and children, this paper makes an important contribution to the literature on immigrant optimism.

To start with, using data from Spain, we show that optimism regarding educational futures is more likely to be the result of parental expectations than of children's. With our analysis, we also try to elucidate the reasons behind the smaller correlation between school results and educational expectations among migrants (which we estimate around 6 per cent). We present two main explanations of this regularity. First, our evidence contradicts the argument that information asymmetries produce optimism. Even after introducing a parental assessment of whether their offspring's level of academic performance is good enough to reach tertiary education and controlling for objective performance (repetition of school year), migrant parents are still more likely to report optimistic expectations. They expect their children to attend university even when they are uncertain or think that their child's current performance is poor and that they do not have the required level of school results. Second, our findings lend support to the migrant selectivity argument. We interpret the resilience of migrant parents to their children's failure in school as proof that optimism is driven by a migrant specific approach to the future. In our view, migration is an expression of an identity that is linked with resilience and hope. As suggested by the literature on selectivity, immigrant optimism is associated with the confounder that it is those with more hopeful and optimistic outlooks who migrate. First movers, including parents, are more clearly bearers of this hopeful outlook. Our evidence shows that the children of migrants, and more generally tied movers, may not always reflect this optimistic approach to the future.

Like most research on immigrant optimism, our analysis is also limited to economic migrants from low skilled backgrounds. A promising line of future research would study whether only low skilled economic migrants display this type of aspiring identity or if it is also the case among the highly skilled. Future research should also attempt to overcome data limitations by using multi-sited evidence, which would allow linking migrants in destination with non-migrants in origin to explore whether those moving across borders are indeed more aspirational and optimistic than those choosing to stay. 


\section{Appendix}

Table A.1. Descriptives.

\begin{tabular}{|c|c|c|c|c|c|c|}
\hline CHILDREN & & $\mathrm{N}$ & Mean & S.d. & Min. & Max. \\
\hline \multirow[t]{6}{*}{ Non-migrant } & Likelihood of reaching university & 1410 & .58 & .49 & 0 & 1 \\
\hline & Own assessment of performance & 1410 & 1.2 & .78 & 0 & 2 \\
\hline & Highest level of parental education & 1410 & 3.2 & .61 & 2 & 4 \\
\hline & Grade repetition & 1410 & .32 & .47 & 0 & 1 \\
\hline & Female student & 1410 & .46 & .5 & 0 & 1 \\
\hline & Age of arrival in Spain & 1410 & 15 & 1.5 & 0 & 19 \\
\hline \multirow{6}{*}{ Migrant origin } & Likelihood of reaching university & 749 & .45 & .5 & 0 & 1 \\
\hline & Own assessment of performance & 749 & 1.1 & .68 & 0 & 2 \\
\hline & Highest level of parental education & 749 & 3.3 & .61 & 2 & 4 \\
\hline & Grade retention & 749 & .58 & .49 & 0 & 1 \\
\hline & Female student & 749 & .53 & .5 & 0 & 1 \\
\hline & Age of arrival in Spain & 749 & 7 & 3.8 & 1 & 18 \\
\hline \multicolumn{7}{|l|}{ PARENTS } \\
\hline \multirow[t]{5}{*}{ Non-migrant } & Likelihood of reaching university & 738 & .62 & .48 & 0 & 1 \\
\hline & Parental assessment of performance & 741 & 1.3 & .79 & 0 & 2 \\
\hline & Highest level of parental education & 1410 & 3.2 & .61 & 2 & 4 \\
\hline & Grade repetition & 1410 & .32 & .47 & 0 & 1 \\
\hline & Female student & 1410 & .46 & .5 & 0 & 1 \\
\hline \multirow[t]{5}{*}{ Migrant origin } & Likelihood of reaching university & 292 & .62 & .49 & 0 & 1 \\
\hline & Parental assessment of performance & 295 & 1.4 & .74 & 0 & 2 \\
\hline & Highest level of parental education & 749 & 3.3 & .61 & 2 & 4 \\
\hline & Grade repetition & 749 & .58 & .49 & 0 & 1 \\
\hline & Female student & 749 & .53 & .5 & 0 & 1 \\
\hline
\end{tabular}


Table A.2: HLM Regression results for family clustering

\begin{tabular}{|c|c|c|}
\hline & & $(1)$ \\
\hline Migrant origin & & $\begin{array}{c}0.226^{* * *} \\
(0.06)\end{array}$ \\
\hline $\begin{array}{l}\text { Parental education } \\
\text { (ref. is primary or less) }\end{array}$ & Secondary & $\begin{array}{l}0.036 \\
(0.04)\end{array}$ \\
\hline & University & $\begin{array}{c}0.204^{* * *} \\
(0.04)\end{array}$ \\
\hline & Female & $\begin{array}{c}0.040^{*} \\
(0.02)\end{array}$ \\
\hline Grade repetition & & $\begin{array}{c}-0.364 * * * \\
(0.03)\end{array}$ \\
\hline Type of respondent & $\begin{array}{l}\text { Child } \\
\text { (ref. parent) }\end{array}$ & $\begin{array}{l}0.046 \\
(0.04)\end{array}$ \\
\hline Interaction & Child*migrant & $\begin{array}{l}-0.099 \\
(0.08)\end{array}$ \\
\hline Assessed performance & $\begin{array}{l}\text { Does not know } \\
\text { Yes, enough }\end{array}$ & $\begin{array}{c}0.182^{* * *} \\
(0.04) \\
0.362^{* * *} \\
(0.04)\end{array}$ \\
\hline Interactions & Does not know*migrant & $\begin{array}{r}-0.089 \\
(0.08)\end{array}$ \\
\hline & Yes, enough*migrant & $\begin{array}{c}-0.218^{* * *} \\
(0.07)\end{array}$ \\
\hline & Does not know*child & $\begin{array}{l}0.034 \\
(0.05)\end{array}$ \\
\hline & Yes, enough*child & $\begin{array}{c}-0.046 \\
(0.05)\end{array}$ \\
\hline & $\begin{array}{l}\text { Does not } \\
\text { know*migrant*child }\end{array}$ & -0.122 \\
\hline & $\begin{array}{l}\text { Yes, } \\
\text { enough*migrant*child }\end{array}$ & $\begin{array}{c}(0.103) \\
0.05\end{array}$ \\
\hline Constant & & $\begin{array}{c}(0.098) \\
0.367 * * * \\
(0.06)\end{array}$ \\
\hline Model information & $\begin{array}{l}\mathrm{N} \text { of individuals } \\
\mathrm{N} \text {. of families }\end{array}$ & $\begin{array}{l}2074 \\
1044\end{array}$ \\
\hline
\end{tabular}


Figure A.1. Children's expectations of reaching tertiary education by migrant background

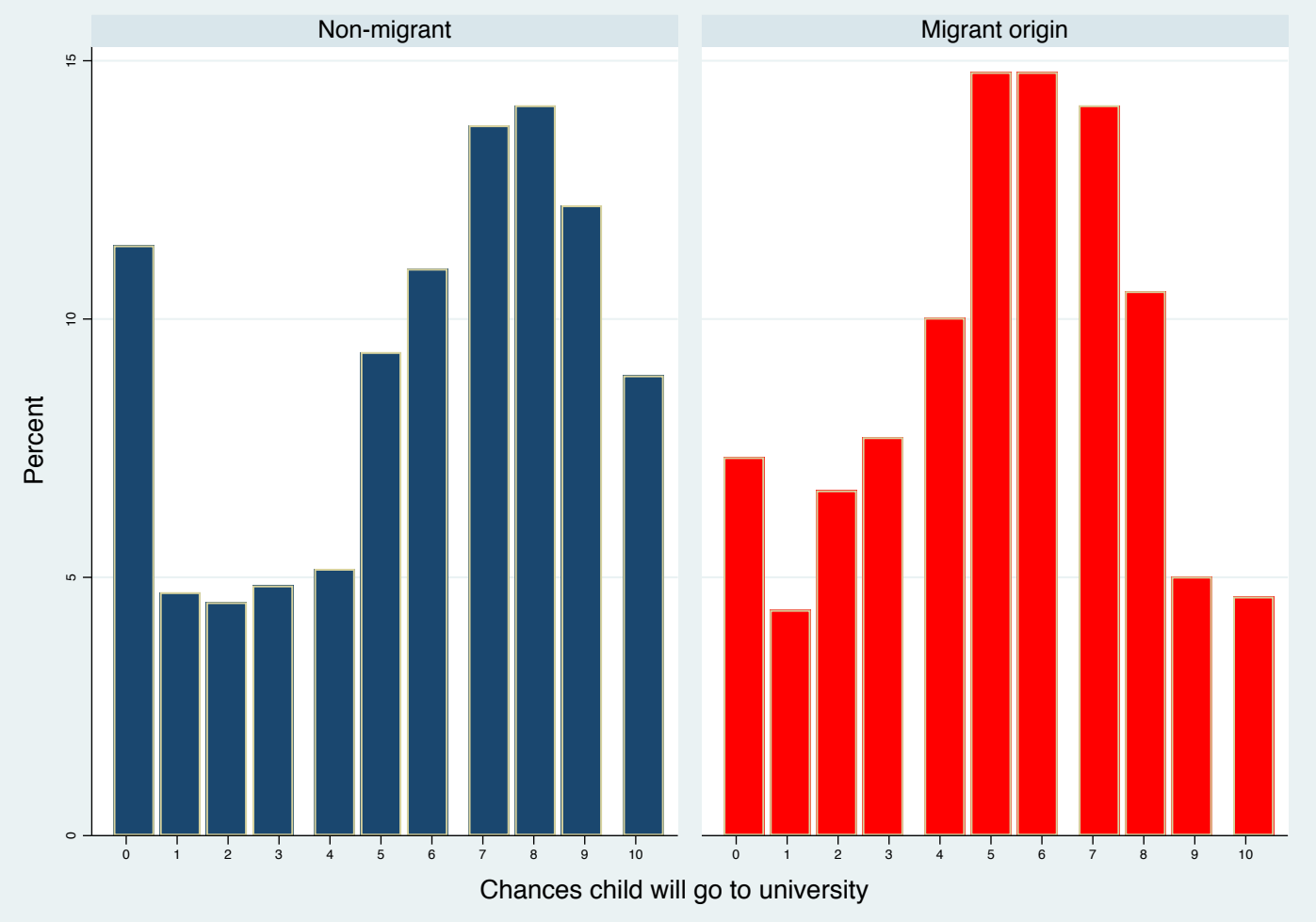

Source: Chances 2011 ( "In a scale of 0 to 10 how likely you think you will attain tertiary education?") 


\section{References}

Byun, Soo-yong, and Hyunjoon Park. 2012. "The Academic Success of East Asian American Youth The Role of Shadow Education." Sociology of Education 85 (1): $40-60$.

Cebolla Boado, Héctor, and Amparo González Ferrer. 2013. Inmigración: ¿integración sin modelo? Alianza.

Cebolla Boado, Héctor, and Antidio Martínez de Lizarrondo. 2015. "Las Expectativas Educativas de La Población Inmigrante En Navarra.?’ Optimismo Inmigrante o Efectos de Escuela?" Revista Internacional de Sociología 73 (1).

Cebolla-Boado, Héctor, and Yasemin Nuhoḡlu Soysal. 2017. "Educational Optimism in China: Migrant Selectivity or Migration Experience?" Journal of Ethnic and Migration Studies 44 (13): 2107-2126.

Cummings, Colleen, Karen Laing, James Law, Janice McLaughlin, Ivy Papps, Liz Todd, and Pam Woolner. 2012. "Can Changing Aspirations and Attitudes Impact on Educational Attainment." Report, Joseph Rowntree Foundation.

Dollmann, Jörg. 2015. "Less Choice, Less Inequality? A Natural Experiment on Social and Ethnic Differences in Educational Decision-Making." European Sociological Review 32(2): 203-215.

Engzell, Per. 2019. "Aspiration Squeeze: The Struggle of Children to Positively Selected Immigrants." Sociology of Education 92(1): 83-103.

Feliciano, Cynthia, and Yader R. Lanuza. 2017. "An Immigrant Paradox? Contextual Attainment and Intergenerational Educational Mobility." American Sociological Review 82 (1): 211-241.

Fernández-Reino, Mariña. 2016. "Immigrant Optimism or Anticipated Discrimination? Explaining the First Educational Transition of Ethnic Minorities in England." Research in Social Stratification and Mobility 46: 141-156.

Frye, Margaret. 2012. "Bright Futures in Malawi's New Dawn: Educational Aspirations as Assertions of Identity.” American Journal of Sociology 117 (6): 1565-1624.

García Perales, Ramón, and Carmen Jiménez Fernández. "Relación entre repetición de curso, rendimiento académico e igualdad en educación: Las aportaciones de PISA." Revista Educación, Política y Sociedad (2019).

Gil-Hernández, Carlos J., and Pablo Gracia. 2018. “Adolescents’ Educational Aspirations and Ethnic Background: The Case of Students of African and Latin American Migrant Origins in Spain.” Demographic Research 38: 577-618.

Ichou, Mathieu. 2014. "Who They Were There: Immigrants' Educational Selectivity and Their Children's Educational Attainment." European Sociological Review 30 (6): 750-65.

Jackson, Michelle, Jan O. Jonsson, and Frida Rudolphi. 2012. "Ethnic Inequality in Choice-Driven Education Systems: A Longitudinal Study of Performance and Choice in England and Sweden." Sociology of Education 85 (2): 158-78.

Jonsson, Jan O., and Frida Rudolphi. 2011. "Weak Performance-Strong Determination: 
School Achievement and Educational Choice among Children of Immigrants in Sweden.” European Sociological Review 27 (4): 487-508.

Kao, Grace, and Marta Tienda. 1995. "Optimism and Achievement: The Educational Performance of Immigrant Youth.” Social Science Quarterly 76 (1): 1-19.

Kao, Grace, and Marta Tienda. (1998). "Educational aspirations of minority youth". American Journal of Education 106 (3): 349-384.

Minello, Alessandra, and Nicola Barban. 2012. "The Educational Expectations of Children of Immigrants in Italy." The ANNALS of the American Academy of Political and Social Science 643 (1): 78-103.

Nygard, Olav. 2017. "Early Tracking and Immigrant Optimism: A Comparative Study of Educational Aspirations among Students in Disadvantaged Schools in Sweden and the Netherlands." Comparative Migration Studies 5 (1): 20.

Okeke, Ndidi A., Lionel C. Howard, Beth Kurtz-Costes, and Stephanie J. Rowley. 2009. "Academic Race Stereotypes, Academic Self-Concept, and Racial Centrality in African American Youth.” Journal of Black Psychology 35 (3): 366-387.

Polavieja, Javier G., Mariña Fernández-Reino, and María Ramos. 2018. “Are Migrants Selected on Motivational Orientations? Selectivity Patterns amongst International Migrants in Europe." European Sociological Review 34 (5): 570-88.

Soysal Nuhoglu Yasemin and Hector Cebolla Boado. 2020. Observing the Unobservable: Selectivity Among Chinese Higher Education Students in China and Europe. Frontiers in Sociology, https://doi.org/10.3389/fsoc.2020.00009

Sue, Stanley, and Sumie Okazaki. 1990. "Asian-American Educational Achievements: A Phenomenon in Search of an Explanation.” American Psychologist 45 (8): 913.

Teney, Celine, Perrine Devleeshouwer, and Laurie Hanquinet. 2013. "Educational Aspirations among Ethnic Minority Youth in Brussels: Does the Perception of Ethnic Discrimination in the Labour Market Matter? A Mixed-Method Approach." Ethnicities 13 (5): 584-606.

Tjaden, Jasper Dag, and Christian Hunkler. 2017. "The Optimism Trap: Migrants' Educational Choices in Stratified Education Systems." Social Science Research 67 (September): 213-28.

Van De Werfhorst, Herman G., and Frank Van Tubergen. 2007. "Ethnicity, Schooling, and Merit in the Netherlands." Ethnicities 7 (3): 416-44.

Van Den Werfhorst, Herman G. van de, and Anthony Heath. 2019. "Selectivity of Migration and the Educational Disadvantages of Second-Generation Immigrants in Ten Host Societies." European Journal of Population 35 (2): 347-378.

Xie, Yu, and Kimberly Goyette. 1997. "The Racial Identification of Biracial Children with One Asian Parent: Evidence from the 1990 Census." Social Forces 76 (2): 547-570. 